\title{
The corrosion-resistant Ni-based coatings and their tribological properties
}

\section{Korózne odolné povlaky na báze $\mathrm{Ni}$ a ich tribologické vlastnosti}

\author{
Zdravecká E., Tkáčová J.
}

Technická Univerzita v Košiciach, Slovensko

E-mail: jana.tkacova@tuke.sk

Ni-based coatings can be successfully applied under abrasive and adhesive conditions as a substitute for environmentally harmful chrome coatings. The research has been carried out for thermally flame sprayed Ni-based coatings with remelting (so-called the two-step process) with the different chemical composition of starting powders. The structure of coatings was evaluated by optical and scanning electron microscopy. Both the three-body abrasive wear test, according to ASTM G65-4 (Dry-Sand Rubber Wheel Test) and dry sliding wear test by the Falex tester, were performed. The results show the influence of the effective chemical composition of the metal powders on improving the properties of the coating. The higher hardness of the coatings leads to a lower tendency for the creation of adhesive bonds, and as a result, leads to a lower tendency to scuffing. A similar trend shows the influence of higher coating hardness on the increasing of abrasive wear resistance.

\section{INTRODUCTION}

Thermally sprayed Ni-base coatings are currently considered to be a potential and environmentally friendly substitute for conventional electroplated hard chromium layers. Electro deposited hard chromium plating is generally used to produce hard and wear-resistant coatings but, the plating baths contain hexavalent chromium, which has adverse health and environmental effects [1,2].

Thermal spraying involves many deposition processes, such as flame spraying, plasma spraying, highvelocity oxy-fuel (HVOF) spraying, and cold spraying to produce the coatings with various chemical composition, structure, and thickness $[3,4]$.

The flame sprayed coatings are prone to the formation of interconnected elongated pores due to the lack of the fusion between sprayed particles or due to the expansion of gases generated during the spraying process. Subsequently, lower adherence to the substrate can deteriorate the quality of these coatings. One of the possible methods of reducing porosity, improving adhesion and mechanical and tribological properties of thermally sprayed coatings is the application of the
Povlaky na báze Ni je možné úspešne aplikovat’ pre abrazivne a adhézne podmienky ako náhradu za environmentálne škodlivé chrómové povlaky. Výskum bol uskutočnený pre žiarovo plameňom striekané povlaky na báze $\mathrm{Ni}$ s pretavením (tzv. dvojkrokový proces) s rôznym chemickým zložením východiskových práškov. Śtruktúra povlakov bola vyhodnotená optickou a skenovacou elektrónovou mikroskópiou. Realizovaný bol test abrazivneho opotrebenia pri trojbodovom dotyku podl'a ASTM G65-4 (Dry-Sand Rubber Wheel Test) a test na opotrebenie kízaním pomocou Falex testera. Výsledky ukazujú vplyv chemického zloženia kovových práškov na vylepšenie vlastnosti povlakov. Vyššia tvrdost' povlakov vedie $k$ nižšej tendencii vytvárania adhéznych spojov a v dôsledku toho $k$ nižšej tendencii k odieraniu. Podobný trend ukazuje vplyv vyššej tvrdosti povlaku na zvýšenie odolnosti proti abrazivnemu opotrebeniu.

remelting process (flame treatment, thermal treatment, laser post-treatment, etc.) [4-6].

Ni-based alloys are used in wide range of applications, especially requiring wear resistance combined with resistance to oxidation or corrosion at high temperatures [7]. Chromium promotes resistance to oxidation and high-temperature corrosion and increases the hardness of the coating by forming hard precipitates. Boron brings down the melting temperature and helps the formation of hard phases. Silicon is added to increase self-fluxing properties. Carbon produces carbides with high hardness levels that improve the wear resistance of coatings. It is important to provide an effective and economical amount of alloying elements in the starting powders. However, it was also reported that the abrasive resistance can vary for different types of materials and coatings even for materials with very similar hardness $[4,8]$.

Ni-based coatings are generally applied to provide higher wear protection, and therefore, it is important to study their tribological properties. The tribological properties of materials are influenced by mechanical properties (e.g. elastic modulus, yield strength, hardness 
or fracture toughness) that are well defined for metallic materials. However, there are no simple equivalents of these properties for thermally sprayed coatings. This is due to the complexity of the structure of the thermally sprayed materials (e.g. hard phases, cracks, lamellar structure, pores) [9].

In the present work, the aim was to obtain information about the influence of remelting (two-step technology) on resistance to scuffing and abrasion of selected Ni-based self-fluxing alloy coatings made of two innovative starting powders. The tribological performance of tested coatings by two test methods, i.e., the three-body abrasion test and the Falex scuffing test, are compared and discussed.

\section{EXPERIMENTAL}

\section{Materials}

The innovative metallic Ni-based self-fluxing alloy powders with an average grain size of $-100 \mu \mathrm{m}+45 \mu \mathrm{m}$ and the melting point of $1010{ }^{\circ} \mathrm{C}$ were used as the coating material (Welding Research Institute, PI, Slovakia). The chemical composition of the studied powder materials (marked as A and B) is given in Table 1. The shape of powder grains is shown in Figure 1. The transverse section of the coatings was polished using the standard

Tab. 1. Chemical composition of powders / Chemické zloženie práškov

C: 0.25, Si: 3.9, Mn: 0.08, P: 0.001, Cr: 0.12, Mo: 0.01,

A B: 0.98, S: $0.006, \mathrm{Fe}: 0.51, \mathrm{~W}: 0.02, \mathrm{Cu}: 0.1, \mathrm{Co}: 0.02$, Ti: $0.02, \mathrm{Nb}<0.0, \mathrm{Ni}: 94.49$

C: 0.21, Si: 3.52, Mn: 0.07, P: 0.057, Cr: 8.85, Mo: 1.30,

B B: $1.48, \mathrm{~S}: 0.012, \mathrm{Fe}: 2.63, \mathrm{~V}: 0.01, \mathrm{~W}: 0.02, \mathrm{Cu}: 0.73$, Al: $0.004, \mathrm{Co}: 0.02$, Ti: $0.01, \mathrm{Ni}: 81.4$

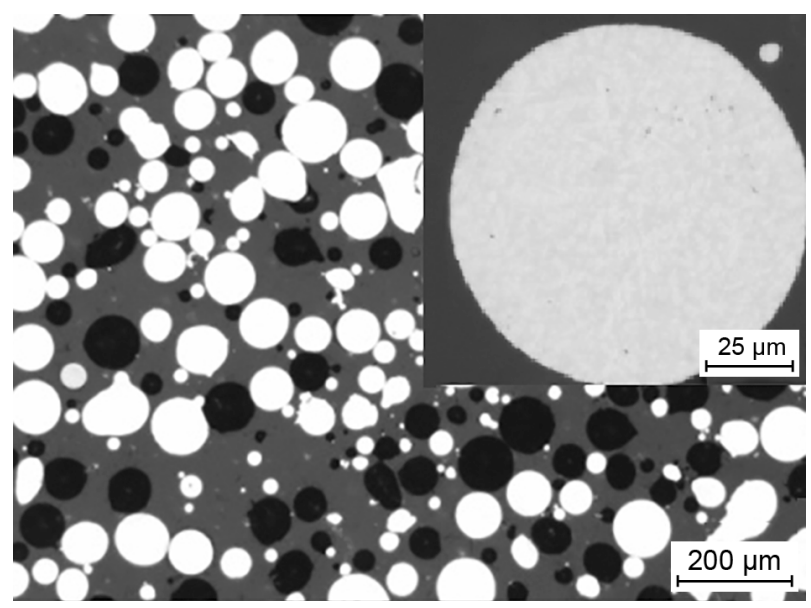

a)

Fig. 1. Transverse section of powder A (left) and B (right) Obr. 1. Priečny rez práškom A (vlavo) a $B$ (vpravo) metallographic procedure. The powder particles showed a spheroidal shape. The powder of type B contains the hard chromium carbides in the Ni matrix [10].

\section{Coatings}

Coatings were deposited on the plate (dimensions $100 \times 150 \times 8 \mathrm{~mm}$ ) made of hot rolled low carbon steel S35530 EN10027-1 (1.0553). The surfaces of the blocks were shot blasted to remove grease and oxides and to stimulate adherence of the layers to be sprayed. The surface roughness of approximately $\mathrm{Ra} \approx 5.0 \mu \mathrm{m}$ was chosen to provide adhesion and the proper contact properties. The number of samples for each experimental test was three.

The samples before spraying were preheated to a temperature between $90{ }^{\circ} \mathrm{C}$ and $100{ }^{\circ} \mathrm{C}$. A suitable substrate temperature increases the adhesion of the thermally sprayed coating.

The SuperJet Eutalloy oxy-acetylene thermal spray system was used for the flame spray process at a pressure of $100 \mathrm{kPa}$ for the oxygen and $70 \mathrm{kPa}$ for the acetylene. The spray distance between the gun and the substrate was $200 \mathrm{~mm}$. Flame remelting consists of applying an oxy-acetylene flame to the coatings until a melting temperature of $1025^{\circ} \mathrm{C}$ is reached.

\section{Methods}

The structure of thermally sprayed coatings was investigated by cross-sectioned specimens with the Neophot 21 optical microscope and SEM. The etching with a mixture of $\mathrm{HF}(10 \mathrm{ccs})$ and $\mathrm{HNO}_{3}(100 \mathrm{ccs})$ was carried out. The Rockwell hardness measurements were carried out after grinding. Microhardness measurements on cross-sectioned specimen were performed by the Hanemann's hardness tester HV0.3 with a constant load of $300 \mathrm{~g}$.

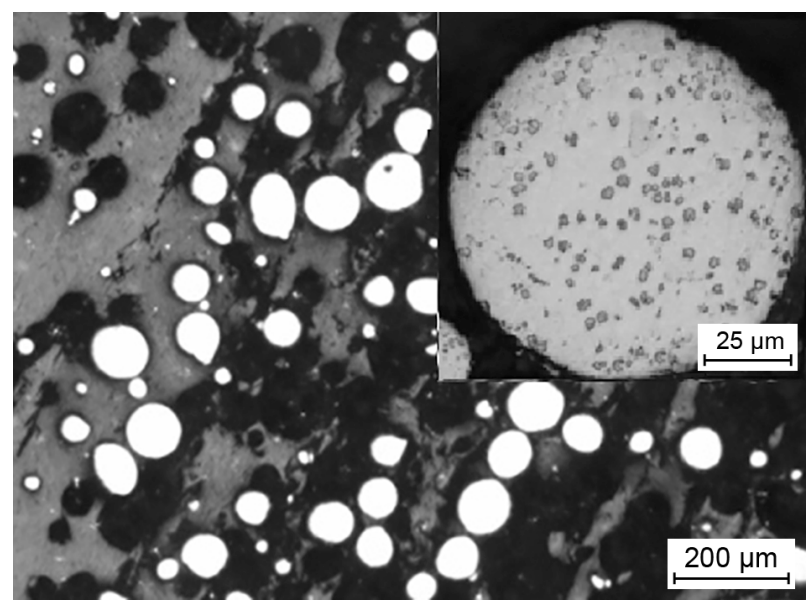

b) 
The study of the tribological performance of the coatings was carried out by two test methods. The originally designed three-body abrasion tester, according to the ASTM standard G65-4, known as the Dry-Sand Rubber Wheel (DSRW), was used Figure 2a [11]. The principle of the test is shown in Figure $2 b$. The parameters of the test were as follows: sliding distance: $1031 \mathrm{~m}$, wheel speed: $2.3 \mathrm{~m} \mathrm{~s}^{-1}$, load: $35.5 \mathrm{~N}$. As abrasive, angular $\mathrm{SiO}_{2}$ particles (hardness 1000-1200 HV) with $0.36 \mathrm{~mm}$ average size were used. The abrasion test was repeated three times for the materials used, and the average mass loss $\Delta \mathrm{m}[\mathrm{g}]$ was calculated.

The Falex tribometer - journal and vee block tester(IT-09 ITE Radom) was used to evaluate the tribological properties of tested samples under dry sliding according to ASTM standards (Fig. 3a). The dimensions of coated samples with the groove on the face surface (V-blocks) were as follows: diameter $\mathrm{D}=12.7 \pm 0.05 \mathrm{~mm}$, length $\mathrm{L}=10.0 \pm 0.05 \mathrm{~mm}[10]$.

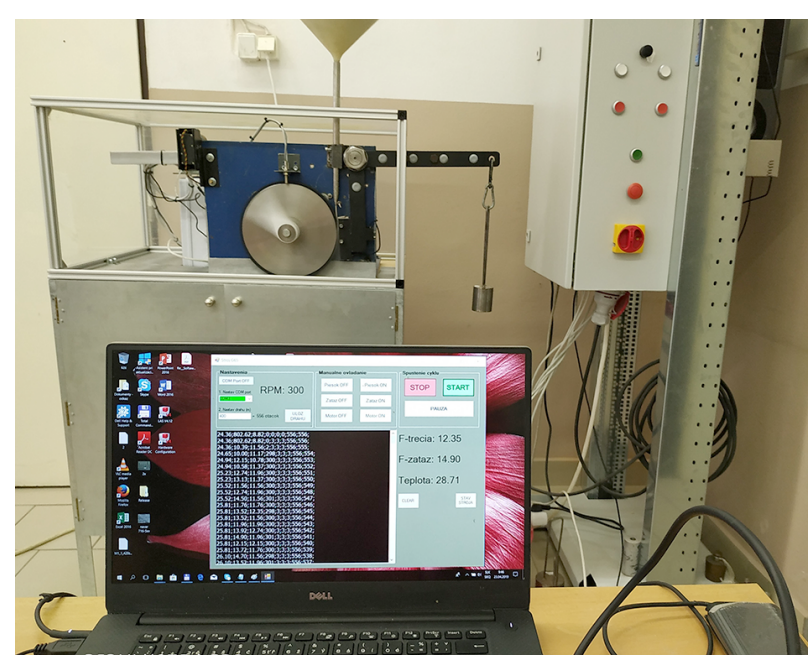

a)

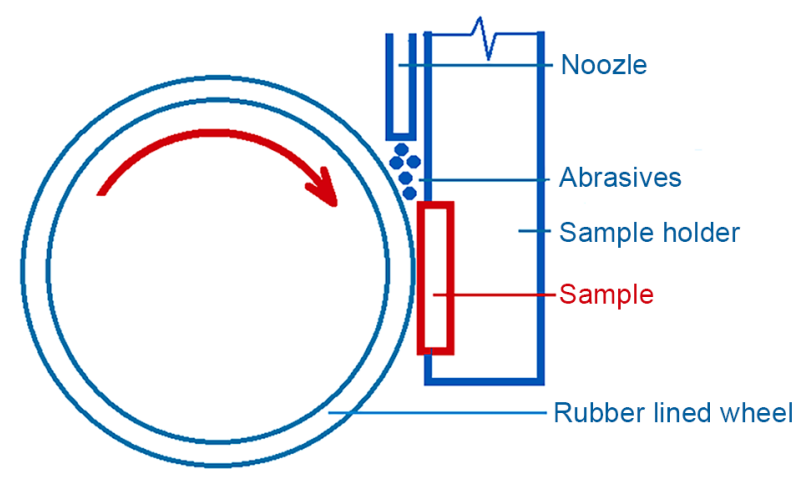

b)

Fig. 2. Three body wear test: a) view on tribometer [11], b) scheme of tribometer

Obr. 2. Skúškaopotrebeniastrojbodovýmdotykom:a)pohlad na tribometer, b) schéma tribometra
During the dry sliding test, pressure force $\mathrm{P}$ is acting on two vee blocks pressed on a rotating pin. The maximum pressure force $\mathrm{P}$ is up to $20 \mathrm{kN}$. Rotating pin between the tested samples was pinned by a uniformly increased force up to scuffing occurred (Fig. 3b). The speed of the pin rotating between prismatic faces was constant during the tests $v=200 \mathrm{rpm}$ under dry conditions. The material of the pin was $\mathrm{St} 45$ steel with chemical composition: C: $0.42-0.50 \%, \mathrm{Mn}: 0.50-0.80 \%$, Si: $0.37 \%$, Cr: $0.30 \%$, Ni: $0.30 \%, \mathrm{Cu}: 0.30 \%$, its hardness after heat treatment was 50-55 HRC [10]. The wear resistance was determined as the maximum force $F_{\max }$ at which the galling occurred and the test was stopped. The $\mathrm{F}_{\max }$ was measured and the mean value was calculated from three samples for each coating. The microhardness of the HV0.3 coating was measured on the coating cross-sections (Hanemann HV0.3 hardness tester). The reported values are an average of at least 10 measurements. The cross-sections of coatings observed by the light microscope are shown in Figs. 4 and 5.

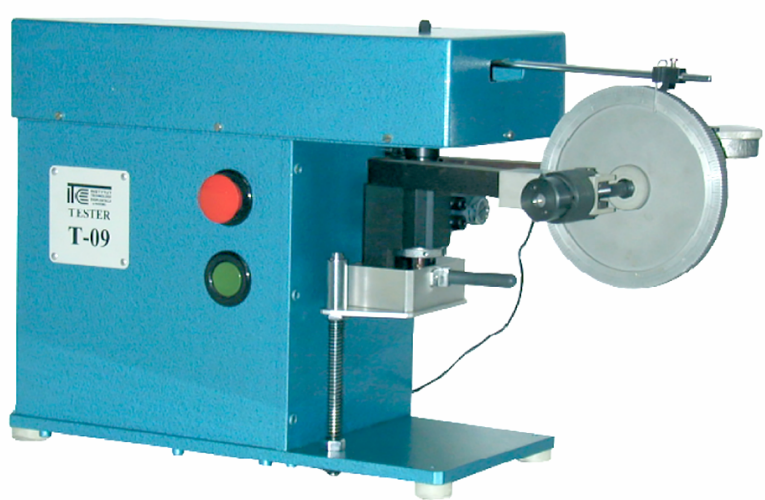

a)

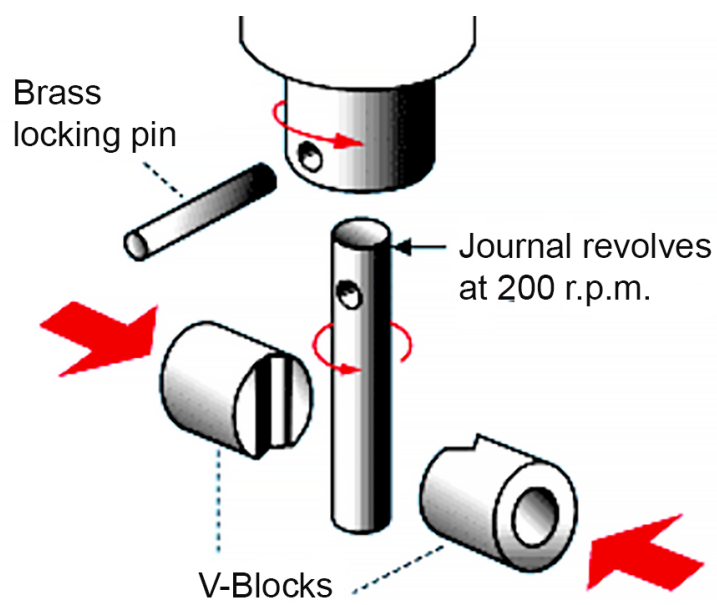

b)

Fig. 3. Falex tribometer a) view on tribometer, b) pin and vee block of tribosystem

Obr. 3. Falex tribometer a) pohlad na tribometer, b) kolík a V-blok tribosystému 


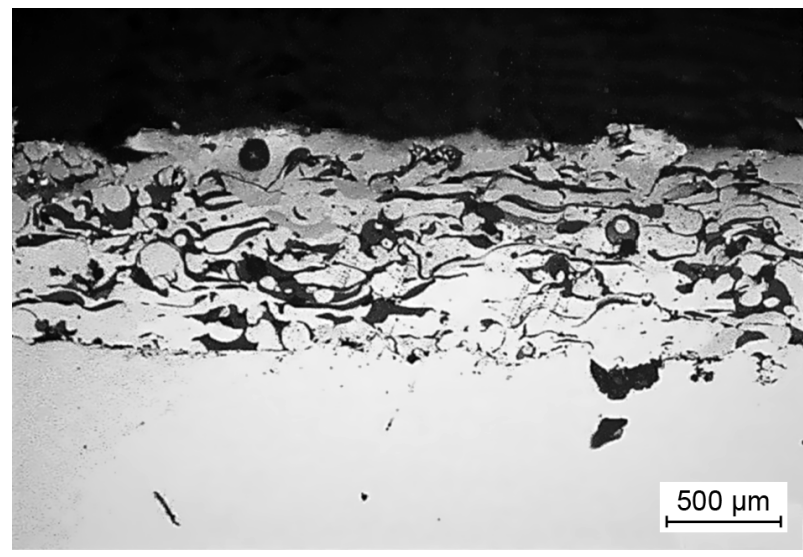

a)

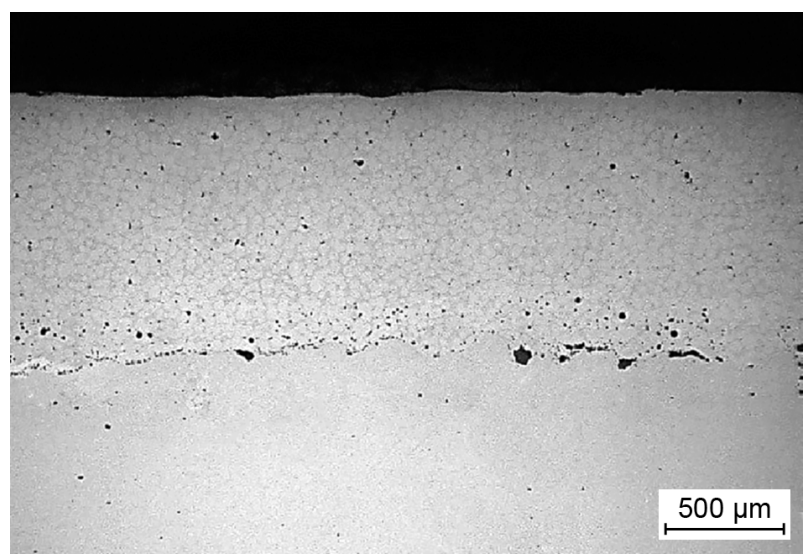

b)

Fig. 4. The cross-section of coating $A$ before remelting (left) and after remelting (right)

Obr. 4. Prierez povlaku A pred pretavením (vlavo) a po pretavení (vpravo)

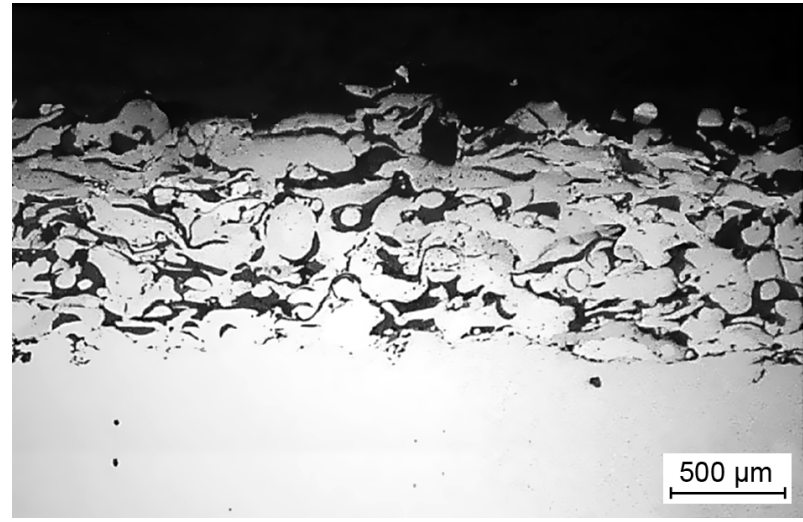

a)

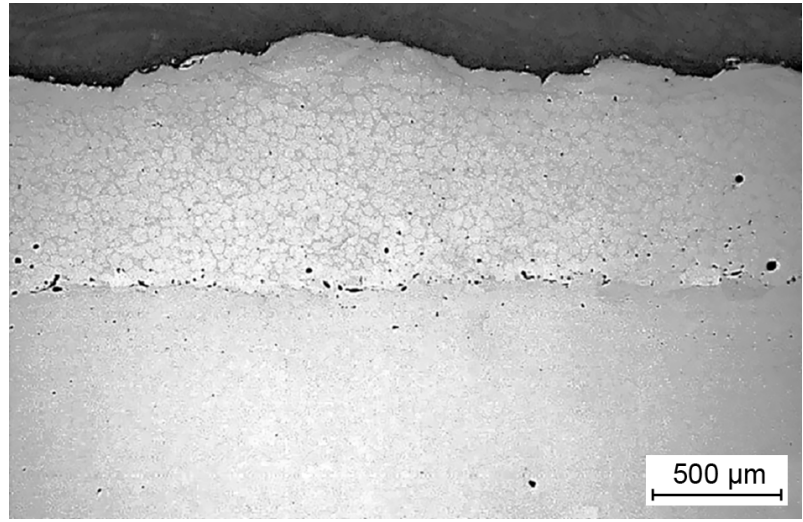

b)

Fig. 5. The cross-section of coating B before remelting (left) and after remelting (right)

Obr. 5. Prierez povlaku B pred pretavením (vlavo) a po pretavení (vpravo)

\section{RESULTS AND DISCUSSION}

\section{Structure and hardness}

The layer thickness of coatings was approximately 1.5-2 mm. Light microscopy images presented in Figures 4 and 5 show cross-sections of coatings: (i.) after flame spraying in and (ii.) after remelting. As is documented, the structures of coatings $\mathrm{A}$ and $\mathrm{B}$ contain pores, unmelted particles, gaps between the splats, and elongated splats. The coatings are mechanically bonded to the substrate $[4,8,12-15]$.

The porosity or splat boundaries of thermal sprayed coatings can be successfully eliminated by different methods of remelting (González et al., 2007). The structures of the coatings $\mathrm{A}$ and $\mathrm{B}$ after remelting show the elimination of the pores and splat boundaries - Figures $4 \mathrm{~b}$ and $5 \mathrm{~b}[8,12]$.

The interface between coatings and the substrate after remelting is without defects, pores, and with the metallurgical bond. Adhesion has been reinforced using the substrate preheating process and remelting for suitable bonding strength [16-18].

The structure of middle region of remelted coatings is shown in Figure 6. The figure displayed the microstructure of coatings A with increased grain size, which may be influenced by a heat treatment time [4].

As reported by Gonzáles et al. (2007) it is difficult to control the temperature-time cycle, the final throughthickness microstructure is not homogeneous [19, 20]. Darker areas in Figure 6a indicate fewer precipitates in coating $\mathrm{A}$. The remelting of the coating reduces porosity and creates a strong metallurgical bond [4, 8, 17]. The elimination of the pores by remelting was confirmed (Fig. 6). The precipitates in coating B are dissolved in the Ni matrix.

Table 2 presents the results of tribological tests and the hardness of tested coatings. The micro-hardness of A coating is approximately $290 \pm 36 \mathrm{HV} 0.3$, which is slightly lower than the hardness of B coating $409 \pm 43$ HV0.3. The chemical composition of the starting powders 
(Tab. 1) corresponds to the quantity and size of the hard precipitates in the Ni matrix, which are responsible for the differences of the hardness of the coatings.

\section{Wear testing}

Tab. 2 presents the results of abrasive wear of coatings $\mathrm{A}$ and $\mathrm{B}$ under three-body abrasion tests. The better resistance to abrasive wear was recorded for $\mathrm{B}$ coating compared to coating A. The coating B exhibits lower mass loss, i.e., higher wear resistance, which is consistent with its higher hardness. The chemical composition of the starting powders influences on the creation of the hard phases in the Ni matrix. However, it is also important to use optimized parameters of thermally sprayed processes. Phase diagrams, e.g., NiCr, NiB, and NiSi provide information on the effects of individual alloying elements. They show that the presence of $\mathrm{Cr}$, $\mathrm{Si}$, and $\mathrm{B}$ plays a role in the formation of hard phases $[21,22]$. The Ni coatings contain hard phases, the matrix phase is a solid solution of $\mathrm{Ni}$ with hard precipitates,

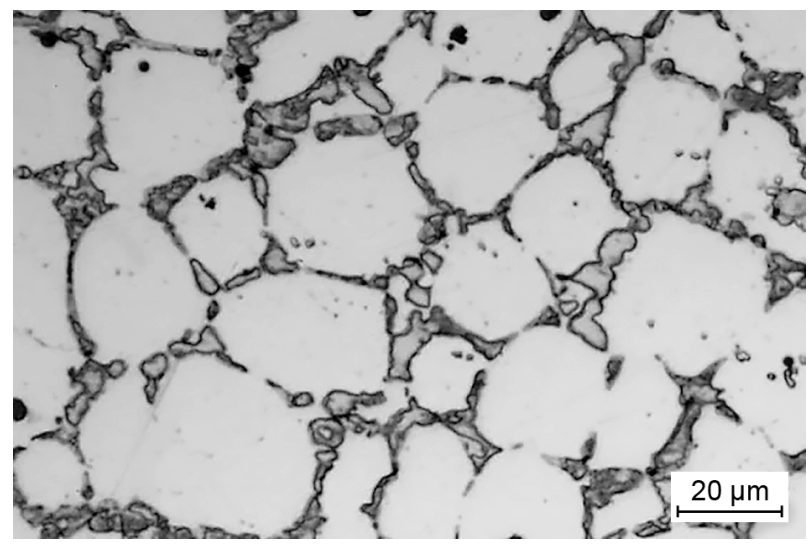

a) mainly of $\mathrm{Cr}$. The coating $\mathrm{B}$ with a higher addition of 2.63 wt.\% Fe exhibits better wear resistance properties, which is consistent with [12].

The tendency to form carbides and borides at higher content of these elements (coating B) is connected with higher microhardness and increased wear resistance. Many researchers have identified carbides and borides of chromium (mainly $\mathrm{Cr}_{7} \mathrm{C}_{3}$ and $\mathrm{CrB}$ ) in solid solution of $\mathrm{Ni}$. The higher hardness of coating $\mathrm{B}$ can be attributed to the strengthening effect provided by the precipitates, such as $\mathrm{CrB}$ and $\mathrm{Ni}_{3} \mathrm{~B}$ phases $[6,8,22,23]$.

Tab. 2. Tribological properties of coatings / Tribologické vlastnosti povlakov

\begin{tabular}{|c|c|c|c|}
\hline Coating & $\begin{array}{c}\text { Mas loss } \Delta \mathbf{m}[\mathbf{g}] \\
\text { ASTM G65-4 }\end{array}$ & $\mathbf{F}_{\max }[\mathbf{N}]$ & $\begin{array}{c}\text { Microhardness } \\
\text { HV0.3 }\end{array}$ \\
\hline $\mathrm{A}$ & $0.0672 \pm 0.019$ & $890 \pm 42$ & $290 \pm 36$ \\
\hline $\mathrm{B}$ & $0.0389 \pm 0.011$ & $1176 \pm 32$ & $409 \pm 43$ \\
\hline
\end{tabular}

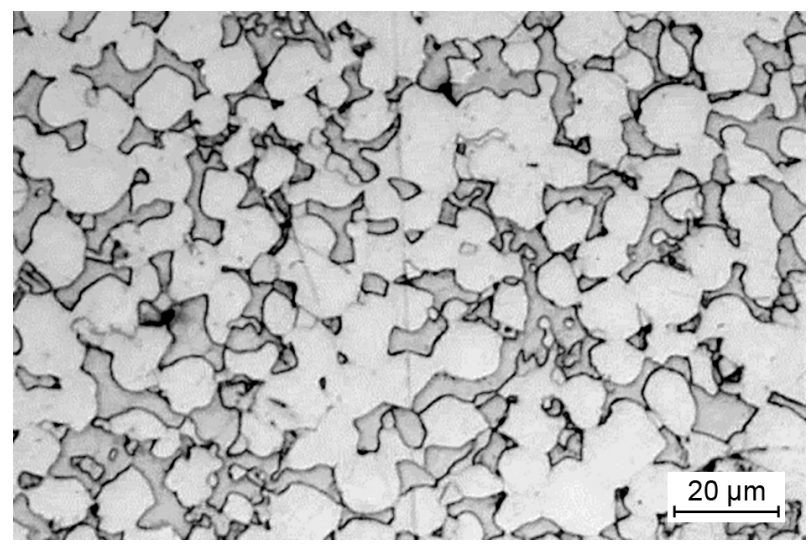

b)

Fig. 6. Structure of middle region - coating A (left) and coating B (right) Obr. 6. Štruktúra strednej oblasti - povlak A (vlavo) a povlak B (vpravo)

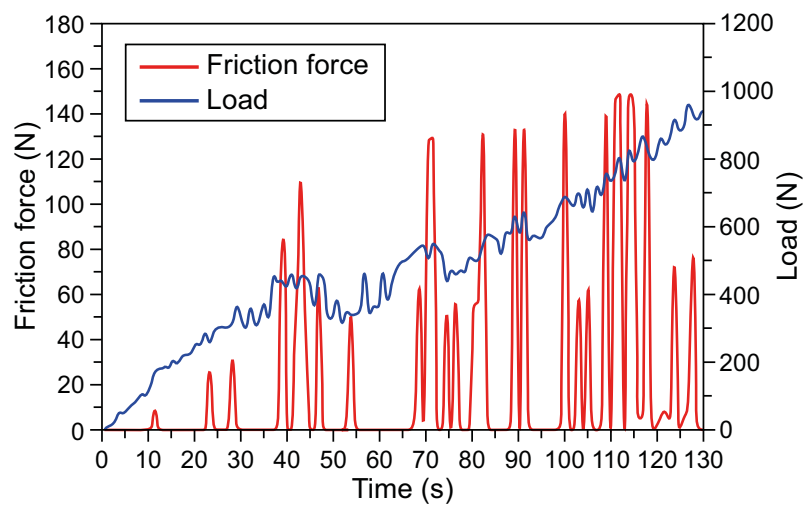

Fig. 7. Scuffing resistance $F_{\text {max }}$ for coating $A$ Obr. 7. Odolnost' proti zadieraniu $F_{\max }$ pre povlak $A$

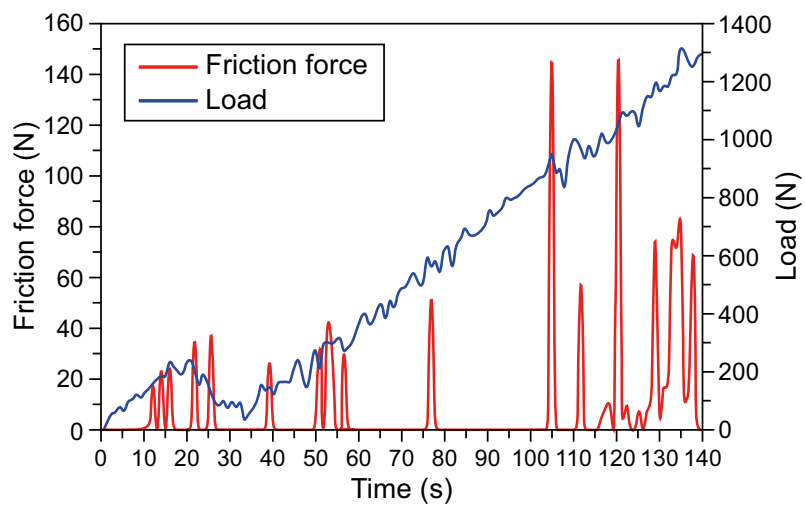

Fig. 8. Scuffing resistance $F_{\max }$ for coating $B$

Obr. 8. Odolnost' proti zadieraniu $F_{\max }$ pre povlak $B$ 
The results of scuffing resistance are presented in Tab. 2 for both coatings tested, where $\mathrm{F}_{\max }$ is the maximum force when scuffing occurs. The selected graphical outputs from Falex tests (Figs. 7 and 8) show that $\mathrm{F}_{\max }$ for coating A recorded a lower value compare to coating B. There are differences in the graphic outputs for tested coatings.

Figure 7 shows the load force for coating A. It can be seen that the oscillations increase with increased load force during the tests. The course of the loading force of coating A shows that, under dry friction conditions, oscillations lead to high scuffing, the scuffing occurred at $\mathrm{F}_{\max }=890 \mathrm{~N}$.

The higher hardness of coating B leads to a lower tendency to oscillations, and therefore, to the lower tendency to form adhesive bonds and to the lower tendency to scuffing (Fig. 8). Wear resistance was determined as a maximum force when scuffing occurred, and the test was stopped. The scuffing occurred at $\mathrm{F}_{\max }=1176 \mathrm{~N}$.

The friction force oscillations are more intense for coating A compared to coating $\mathrm{B}$, resulting in lower scuffing resistance of coating A. Under dry sliding test in steel pin and V-block configuration, coating A showed lower scuffing resistance, while coating B with higher hardness recorded a higher scuffing resistance value.

\section{CONCLUSIONS}

Based on the experimental research of the thermally sprayed Ni-based coatings by a two-step process, the following conclusions can be drawn. The coatings prepared of the Ni-based starting powders showed that an efficient amount of alloying elements (chromium about 8-9 \%, boron about $1.5 \%$, and $\mathrm{Fe}$ ) contributes to the formation of hard phases and to increase in hardness. Experimental tests have shown that the higher hardness of the coatings had a positive effect on increasing the abrasive wear resistance. The higher hardness of the coating resulted in a reduction of adhesive bond formation and thus improvement of scuffing resistance under the Falex test. Two experimental tests performed have confirmed the importance of efficient and economical alloying of starting powders for the tribological behavior of flame deposited coatings with remelting. The obtained results showed that thermally sprayed coatings by twostep technology and optimized chemical composition contribute to improved interface bonding, elimination of splat-structure, reduced porosity, and offer improved tribo-mechanical behavior.

\section{Acknowledgment}

This study was prepared with the support of the VEGA projects 1/0259/19, 1/0432/17, 2/0080/19 2019-2022.

\section{REFERENCES}

1. Liming L., Haifeng X., Jinkun X., Xinlong W., Ga Z., Chao Z.: Effect of heat treatment on structure and property evolutions of atmospheric plasma sprayed NiCrBSi coatings, Surface and Coatings Technology 2017 (325), $548-554$.

2. Kimbrough D.E., Cohen Y., Winer A.M., Creelman L., Mabuni, C.: A Critical Assessment of Chromium in the Environment, Critical Reviews in Environmental Science and Technology 1999 (29), 1-46.

3. Margadanta N., Neuenschwander J., Staussa S., Kapsc, H., Kulkarnid A., Matejicek J., Rossler G.: Impact of probing volume from different mechanical measurement methods on elastic properties of thermally sprayed Ni-based coatings on a mesoscopic scale, Surface and Coatings Technology 2006, (200), 2805-2820.

4. González R., Cadenas M., Fernández M., Cortizo J.L., Rodríguez E.: Wear behaviour of flame sprayed NiCrBSi coating remelted by flame or by laser Wear 2007, (262), 301-307.

5. Hejwowski T., Szewczyk S., Weronaski A.: An investigation of the abrasive and erosive wear of flame-sprayed coatings, Journal of Materials Processing Technology 2000, (106), 54-57.

6. Fernandez E., Cadenas M., Gonzalez R., Navas C., Fernandez R., Damborenea J.: Wear behaviour of laser clad NiCrBSi coating, Wear 2005, (259), 870-875.

7. Sadeghi E., Markocsan N., Joshi, S.: Advances in Corrosion-Resistant Thermal Spray Coatings for Renewable Energy Power Plants. Part I: Effect of Composition and Microstructure, Journal of Thermal Spray Technology 2019, (28), 1749-1788.

8. Serres N., Hlawka F., Costil S., Langlade C., Machi. F.: Microstructures of Metallic NiCrBSi Coatings Manufactured via Hybrid Plasma Spray and In Situ Laser Remelting Process, Journal of Thermal Spray Technology 2011, (20), 336-343.

9. Zuomin L.: Abrasive wear control design of a metal thermal spray coating and its application, Tribology international 2004, (301), 219-225.

10. Zdravecká E., Suchánek J., Tkáčová J., Trpčevská J., Brinkiene $\mathrm{K}$. .: Investigation of wear resistance of high velocity oxy-fuel sprayed $\mathrm{WC}-\mathrm{Co}$ and $\mathrm{Cr}_{3} \mathrm{C}_{2}-\mathrm{NiCr}$ coatings, Mechanika 2010, (84), 75-79.

11. Zdravecká E., Ondáč M., Slota J., Vojs M., Marton M.: Tribometer pre meranie abrazívneho opotrebenia - Tribometer for measurement of abrasion wear, SK200-2015 U1, Banská Bystrica, ÚPV SR, 2017, 7 (in Slovak).

12. Yu J., Wang Y., Zhao X., Li Q., Qiao Q, Zhao J, Zhai S.: Wear Resistance of Ni-Based Alloy Coatings Advances in Materials Science and Engineering 2019, 1-7.

13. Kim H.J., Hwang S.Y., Lee C.H, Philippe J.: Assessment of wear performance of flame sprayed and fused Ni-based coatings, Tribology Letters 2003, (172), 262-269.

14. Arcondeguy A., Grimaud A., Denoirjean A., Gasgnier G., Huguest C., Pateyron B., Montavon G.: Flame-sprayed glaze coatings: effects of operating parameters and feedstock characteristics onto coating structures, Journal of Thermal Spray Technology 2007, (16), 978-990.

15. Navas C., Colaço R., Damborenea J., Vitar R.: Abrasive wear behaviour of laser clad and flame sprayed-melted 
NiCrBSi coatings, Surface and Coatings Technology 2006, (200), 6854-6862.

16. Yin S., Wang X., Suo X., Liao H., Guo Z., Li W., Coddet Ch.: Deposition behavior of thermally softened copper particles in cold spraying. Acta Materialia 2013, (61), 5105-5118.

17. Miguel J.M., Guilemany J.M., Vizcaino S.: Tribological study of NiCrBSi coating obtained by different processes Tribology International 2003, (36), 181-187.

18. Zhang Z., Wang Z., Liang B.: Wear characterization of thermal spray welded $\mathrm{Ni}-\mathrm{Cr}-\mathrm{Si}-\mathrm{RE}$ alloy coatings, Journal of Materials Processing Technology 2009, (209), 1368-1374.

19. GonzálesR., GarciaM.A.,PenuelasI.,CadenasM.,MadelRocio Fernandez, M.R.; Hernandez, Battez A., Felgueroso, D.:
Microstructural Study of NiCrBSi Coatings Obtained by Different Processes, Wear, 2007, (263), 619-624.

20. Grum J., Slabe J.M.: Effect of Laser-Remelting of Surface Cracks on Microstructure and Residual Stresses in $12 \mathrm{Ni}$ Maraging Steel, Applied Surface Science, 2006, (252), 4486-4492.

21. Zhenyu Z., Zhiping W., Bunv L.: Wear characterization of thermal spray welded Ni-Cr-Si-RE alloy coatings, Journal of Materials Processing Technology 2009, (209), 1368-1374.

22. Okamoto H., Schlesinger M.E., Mueller E.M.: ASM Handbook Volume 3: Alloy Phase Diagrams. ASM International, 2016.

23. Bergant Z., Grum J.: Quality improvement of flame sprayed, heat treated, and remelted NiCrBSi coatings, Journal of Thermal Spray Technology 2009, (18), 380-391. 